\title{
CYP3A4 Inhibitor
}

National Cancer Institute

\section{Source}

National Cancer Institute. CYP3A4 Inhibitor. NCI Thesaurus. Code C111373.

Any substance capable of decreasing the activity of cytochrome P450 3A4. 